\title{
NOVAS FESTAS PROFANAS EM ESPANHA
}

\author{
Demetrio E. Brisset \\ Departamento de Comunicacão Audiovisual e Publicidade, Faculdade de Ciên- \\ cias da Comunicação, Universidade de Málaga, Espanha
}

\begin{abstract}
RESUMO
A sociedade espanhola atravessou uma profunda transformação desde a morte do ditador Franco. Uma das suas manifestações mais relevantes relaciona-se com as festas populares. A rígida moral católica que dominava o espaço festivo, controlado pela censura implacável, deu lugar, com a democratização das instituições políticas, a comportamentos festivos profanos, nos quais a vertente lúdica é central. Este artigo pretende resumir a evolução dos rituais festivos nos últimos oitenta anos, destacando as tendências e influências atuais: secularização, coexistência de modelos formais, intervencionismo institucional, integração no quadro europeu, incorporação das mulheres como protagonistas, dinamismo das associações e exaltação de proezas militares. Neste último ponto, destaca-se a conversão do esquema de luta entre duas fações - que monopolizava as celebrações de Mouros e Cristãos, de raízes medievais e baseadas no triunfo da verdadeira religião - em comemorações cívico-históricas (invasões romana e napoleónica, especialmente) de claro conteúdo profano, e mesmo pagão, como é o caso de recentes e numerosas festas na Galiza.
\end{abstract}

\section{PALAVRAS-ChaVe}

Etnohistória; rituais festivos; Franquismo, Espanha; religiosidade

\section{NEW NON-RELIGIOUS FESTIVITIES IN SPAIN}

\begin{abstract}
Spanish society has undergone a profound transformation since the death of dictator Franco. One of its most relevant manifestations relates to popular festivities. The rigid Catholic morality that dominated the festive space, controlled by relentless censorship, gave way, with the democratization of political institutions, to profane festive behaviors, in which the playful aspect is central. This article aims to summarize the evolution of festive rituals in the last eighty years, highlighting the current trends and influences: secularization, coexistence of formal models, institutional interventionism, integration into the European framework, incorporation of women as protagonists, dynamism of associations and exaltation of military powers. In this last point, we highlight the conversion of the scheme of struggle between two factions - which monopolized the celebrations of Moors and Christians, from medieval roots and based on the triumph of true religion - into civic-historical recollections (especially Roman and Napoleonic invasions) of profane and even pagan content, as is the case with recent and numerous festitivies in Galicia.
\end{abstract}

\section{KeYWORDS}

Ethnohistory; festive rituals; Francoism, Spain; religiosity 
Desde a morte do ditador Franco (1975), a sociedade espanhola passou por profundas mudanças sociais e de valores. Os rituais festivos refletiram essas múltiplas transformações.

Desde a época do Concílio de Trento (1545-1563), as autoridades religiosas e civis controlaram estritamente o tempo festivo, limitando as celebrações que giravam em torno da liturgia. Foram muito poucas as festas profanas que lograram escapar, na sua maioria refugiadas no ciclo do carnaval. No final do século XIX, surgiu um novo tipo de festividades naturalistas: as Fiestas del Árbol, que favoreciam a sementeira, transformaram-se em feriado nacional em 1904; seguiram-se as Fiestas del Pez, com truta e salmão fritos. Ambas procuravam reunir a pedagogia com a diversão saudável em ligação com a Natureza. A leste do Cantábrico, para homenagear o herói do mar Juan Sebastián Elcano, é representado desde 1922 em Getaria, sua terra natal, o desembarque do navegador em Sanlucar de Barrameda em 1522, após a acidentada volta ao mundo que durou quase três anos'. Como banquete comunitário, por volta de 1925-28, começou a ser comemorado em Moraña, Galiza, a Festa do Carneiro ou Espeto, dirigida por um jovem argentino que chegou lá dizendo que nas Pampas o principal alimento era o cordeiro, aberto ao meio e assado em churrasco ${ }^{2}$.

Durante os poucos anos de vida da Segunda República, muitas festas desligaram-se dos seus vínculos religiosos, mas após a vitória dos militares sublevados em 1936 e a repressão imposta pelo nacional-catolicismo, o lado lúdico das festividades populares foi novamente aferrolhado pela moral dominante.

Pode dizer-se que a primeira festa essencialmente profana do franquismo nasceu em agosto de 1945 em Bunyol, na região valenciana. Conhecido como La Tomatina, consiste em lançar massivamente tomates e tornou-se uma das festas espanholas mais populares ("A maior luta de comida do mundo", como consta na internet). Aparentemente, o seu nascimento foi casual, quando jovens lançaram tomates a oficiais de justiça, acabando por ser banida sob pena de prisão3. Em resposta, em 1957, decidiram fazer o enterro do tomate, que foi uma grande demonstração paródica, com comparsas e a banda tocando marchas fúnebres. As autoridades municipais tiveram que ceder e, em 1959, foi permitida a sua celebração, limitando o período autorizado para os lançamentos. Esta festividade foi depois institucionalizada e é organizada desde 1975 pelos Clavarios de San Luis Beltrán (o padroeiro da cidade), responsáveis pelo fornecimento dos tomates, que até então cada participante trazia. Em 1980, o município assumiu a organização, aumentando a matéria-prima para várias toneladas e divulgando a festa, na qual não há danos físicos, pois os tomates usados são maduros e macios. Declarada de Interesse Turístico Internacional, a sua popularidade cresceu tanto que, em 2005, reuniu mais de

\footnotetext{
' A representação ocorre a cada quatro anos. Também é lembrada a promessa à Virgem das Dores de Sevilha para que voltassem sãos e salvos. De uma tripulação de 265 homens, apenas 17 retornaram.

${ }^{2}$ Província de Pontevedra, último domingo de julho. Os cordeiros são comprados por grupos de comensais. Desde 1990, foi adicionada no final de agosto a festa do porquiño a brasa, que em 2005 contou com 133 leitões assados.

${ }^{3}$ Consultado em "Historia de la tomatina", disponível em www.lahoya.net/tomatina/histoes.html. O modelo desta manifestação parece ser a Ambaixá de los Tomaques dos Mouros e Cristãos de Cocentaina, no início do século XX.
} 
40000 pessoas, decidindo então as autoridades limitar a assistência a metade e realizar o recontro num recinto pago, onde em 2018 foram lançadas 145 toneladas de tomate e foram credenciados jornalistas de 70 meios de comunicação de todo o mundo. Inclusivamente, foi criada uma imitação na Índia. Similar crescimento festivo exponencial acontece com o Cascamorras, personagem peculiar que sai de Guadix para sequestrar a imagem da Virgen de la Piedad que é venerada na cidade vizinha de Baza, onde milhares de pessoas correm com ele até à igreja e são sujas com tinta escura. Não alcançando esse propósito, retorna à sua cidade natal três dias depois, onde é esperado por outra multidão, que também se transforma numa massa colorida e etílica. Em Buñol, como em Baza, as celebrações são replicadas para crianças, que serão os seus futuros atores.

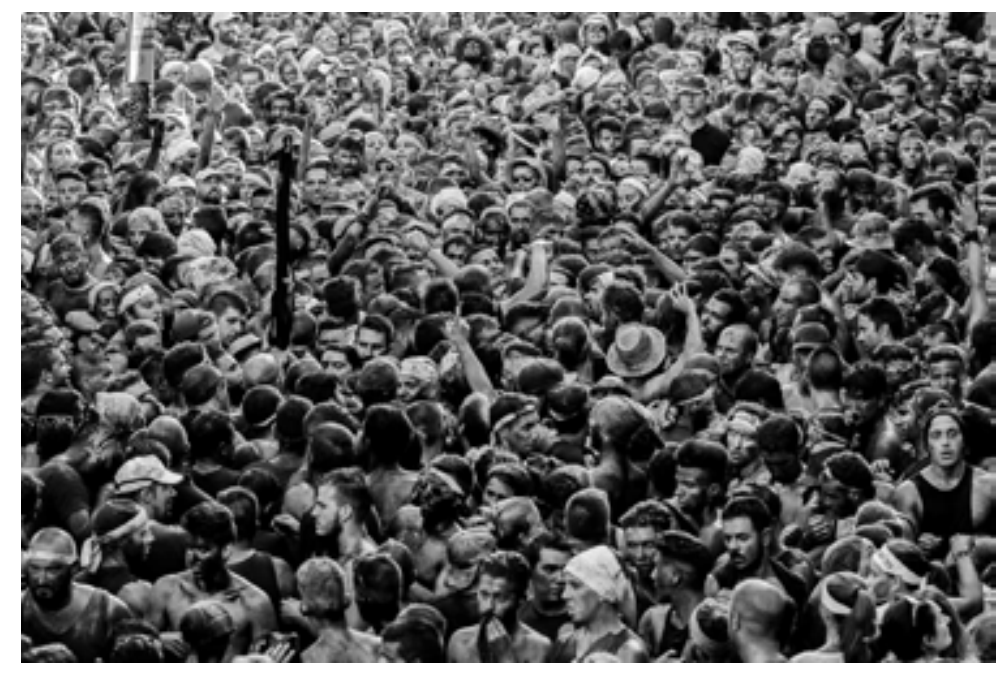

Figura 1: Cascamorras (2018) na província de Granada Créditos: Moisés Gallardo

Outras festas que sofreram censura foram os carnavais de Tenerife. Proibido como todos os carnavais em 1937, apesar disso, em 1950, foram de novo celebrados, tendo sido, em 1954, dissolvidos pela polícia, com muitos detidos. Em 1961, o bispo da diocese mudou o seu nome para Festas de Inverno, e foram novamente autorizados ${ }^{4}$. Também foram autorizadas as inocentes batalhas de flores, que a corte de Bourbon tanto apreciava, como aconteceu em 1956 com a Gala Floral de Torrelavega, na Cantábria, onde desfilavam também carros alegóricos. Embora possa parecer uma mentira, nos últimos dias de Franco, durante a noite mágica de São João, foi celebrado publicamente um aquelarre, precisamente na caverna de Zugarramurdi nos Pirinéus, nefastamente famosa pelos processos inquisitoriais. Nesta esplêndida gruta, o Skal Club de Navarra organizou um espetáculo de luz e som juntamente com um festival folclórico, culminando na cidade vizinha com a quema de la bruja (Ministerio de Información y Turismo, 1973).

Quanto às festividades de natureza báquica, talvez a primeira tenha sido, em 1947, a de La Vendimia y el Vino, na senhorial Jerez de la Frontera e em homenagem ao vinho

${ }_{4}$ Este carnaval entrou no Guinness Book of Records, quando em 1988 mais de 200 ooo pessoas dançaram salsa na Plaza de España. 
fino feito em adegas de famílias inglesas antigas, sobretudo, abençoando a primeira obrigação do ano e oferecendo-o ao seu patrono, San Ginés de la Jara. A seu exemplo, surgirão a festa do Vinho Albariño em Cambados (Pontevedra), em 1953; em Logroño o da Vindima do Rioja, em 1955 (oferecendo o primeiro mosto à Virgem do Valvanera); a da Vindima de Jumilla (Múrcia), em 1959, e o do Vinho do Condado, em Salvatierra de Minho (Pontevedra), em 1960. Desse modo, graças a um entusiasmo alcoólico compartilhado, transcendendo posições ideológicas, as festas públicas foram timidamente perdendo a rigidez. O melhor aliado do vinho é a comida e uma das atividades desenvolvidas para fomentar a incipiente indústria turística foi a multiplicação de novas celebrações louvando os produtos culinários locais, destacando-se neste esforço o proselitismo de outro galego no governo, Fraga Iribarne, Ministro da Informação e Turismo entre 1962 e 1969. Assim, depois da Festa da Lampreia de Arbo 5 e da Sardiñada de Sada, em 1960, surgem a Festa do Polvo, em O Carballiño, e a dos Frutos do Mar, em O Grove ${ }^{6}$, ambos em 1963; e a do Cozido em Lalín, em 19697. Comprovado o seu sucesso, com participação unânime de nativos e forasteiros, no final do regime de Franco, abundam pela Galiza os festivais em glória de ensopados, empanadas, carnes, peixes e frutos do mar variados ${ }^{8}$, tendência que se espalhou por todo o Estado, dando origem a um sem fim de novas festas9.

Uma etapa fundamental na transformação dos rituais festivos foi o início dos anos 1960, quando o país se modernizava com a chegada de turistas e a saída de emigrantes propiciadas pelo Plano de Estabilização. Naquela época, várias iniciativas festivas com amplas repercussões foram desenvolvidas nas Rias galegas.

Em 1961, em Catoira, os membros do Ateneu de Ullán decidiram recordar os ataques normandos que, entre os séculos IX e XI, devastaram a região do rio Ulla, especialmente o ataque de cerca de cem navios, em 968 , que derrotou as tropas do bispo Sisnando (morto com uma flecha cravada nos olhos) e chegaram a Santiago de Compostela. Para fazer isso, na esplanada ao lado das West Towers, construída para proteger a foz do Ulla, jovens vestidos como guerreiros vikings com enormes chifres e walkirias sensuais, chegam navegando num grande barco, atiram-se ao rio e conquistam as torres gritando "Ursula, Ursula!". Antes do desembarque, é celebrada uma missa na capela românica anexa a uma das torres, em sufrágio da alma do arcebispo Gelmírez de Compostela, nativo da cidade e responsável pelo reforço das defesas. Após a conquista, há uma mejillonada e distribuem-se milhares de litros de vinho ribeiro tinto. Devido ao uso

\footnotetext{
${ }_{5}^{5}$ O presidente da câmara municipal teve a ideia de criar uma festa para promover o vinho de Condado, mas como isso já estava a ser feito em Salvatierra, decidiu variar o objeto festivo.

${ }^{6}$ Dedicado todos os anos a um marisco diferente.

7 Pontevedra, no domingo anterior ao carnaval.

${ }^{8} \mathrm{Em} 1974$, surge a fiesta de la empanada aparece em Bandeira (Silleda). Em 2004, existem centenas de fiestas gastronómicas gallegas, dedicadas à degustação de produtos do mar (bonito, sardinha, xouba, salmão, truta, angula, enguia, lampreia, percebe, ostra, amêijoa, mexilhão, berbigão, lagosta e choco), da terra (grelos, fava, batata, pimenta), da pecuária (cordeiro, chouriço, orelha, caldo de ossos, queijo, requeijão), de pratos elaborados (tripas, tortilha), de sobremesas (panquecas, rosquilhas, melindres, bolos) e de vinhos variados (Díaz, Blanco \& Saldaña, 2004).
}

9 Como exemplo, refira-se Málaga, onde só no mês de abril de 2005 foram organizados festivais do azeite, dos espargos, da morcela e da sopa mondeña, além de um mercado medieval. 
da língua galega, houve problemas com as autoridades e, em 1965, a Romería vikinga ${ }^{10}$ passou a ser organizada pelos trabalhadores de uma fábrica de cerâmica local.

Em 1964, na Pousada Nacional de Baiona, no castelo reabilitado dos condes de Gondomar, as autoridades turísticas decidiram organizar banquetes medievais, onde os supostos condes e sua corte recebem prazenteiramente os comensais. O modelo era o dos banquetes históricos que ocorreram em alguns castelos escoceses. Podemos encontrar aqui o germe dos mercados medievais que virão a espalhar-se por muitas povoações, oferecendo uma saída para atividades artesanais que gozam hoje de notável sucesso.

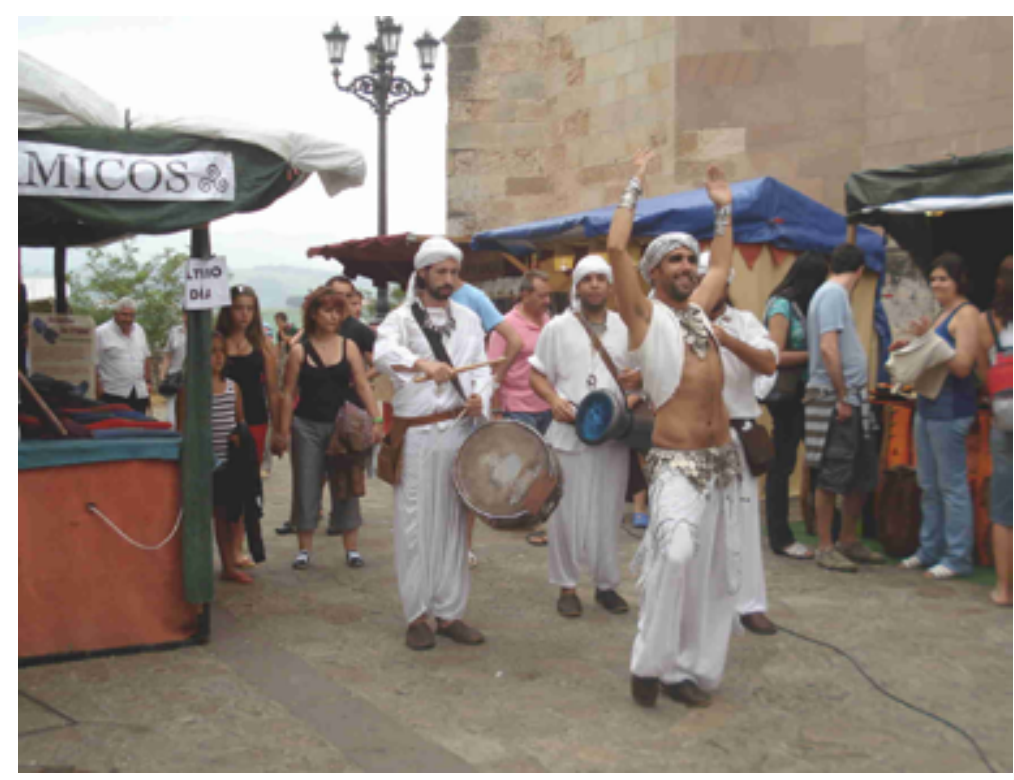

Figura 2: Feira Medieval na Cantábria Créditos: Demetrio Brisset

Estavam lançadas as fundações para as festas da modernidade. A passagem bem-sucedida das festividades em honra aos santos católicos para um tipo de comemoração relacionada com os carnavais profanos precisou apenas de uma mudança de atitudes incentivada por outro contexto social e político, nomeadamente a desintegração do sistema de normas morais após a morte do ditador Franco. Renovaram-se, assim, os símbolos festivos comunitários.

\section{TRANSFORMAÇÃo DOS RITUAIS}

A efervescência social dos anos fascinantes de 1976-77-78 libertou as festas do rígido controlo a que estavam sujeitas. Nas festividades da capital, celebradas a 2 de maio em memória da revolta popular do bairro Maravillas, que desencadeou a Guerra da

\footnotetext{
${ }^{10}$ Ao longo dos anos, a sua espetacularidade cresceu, com construção de um navio drakar viking, participação de personagens noruegueses com guarda-roupa rigoroso. A missa foi relegada e o confronto com os anfitriões do arcebispo e o cativeiro das meninas galegas foram representados teatralmente. Atualmente, milhares de pessoas participam na romaria lúdica e vinícola de Catoira, no primeiro domingo de agosto, declarada de Interesse Turístico Internacional.
} 
Independência, surgiu espontaneamente em 1976, na emblemática Plaza de Malasaña", a transição festiva que levou à mudança, e pode ser considerado o começo de um novo rumo das festividades.

De caráter mais político, no mês seguinte - a 5 de junho de 1976 - ocorreu em Fuentevaqueros, em Granada, a primeira festa manifestamente progressista (excluindo recitais musicais dos cantautores da oposição e homenagens semiclandestinas ao poeta Antonio Machado) que pôde ser celebrada publicamente em Espanha após a Guerra Civil: o Festival de Cultura e Liberdade. O motivo invocado foi a celebração do aniversário de nascimento de Federico García Lorca na sua terra natal, a que se sobrepôs o significado dessa personalidade como poeta latino-americano mundialmente reconhecido e vítima da repressão fascista, conseguindo as forças antifranquistas sair da clandestinidade a pretexto da homenagem ao poeta. Institucionalizada posteriormente como "a festa das 5 às 5", a sua expressão original de protesto tornou-se mero encontro poético-musical, tendo surgido, entretanto, outros canais para encontros coletivos de natureza política.

As autoridades municipais eleitas democraticamente em 1979 sintonizaram-se com o sentimento popular e tentaram timidamente responder a novas demandas, muitas vezes seguindo critérios eleitorais. Nas feiras urbanas, aparecem os escaparates dos partidos de esquerda e, a partir das cidades, expandem-se as novas atitudes festivas pelas áreas rurais, ainda que em muitas localidades, "devido à emigração, não há funcionários jovens que possam organizar as festas" ${ }^{12}$. Em geral, a década de 1980 conheceu uma explosão da componente lúdica da vida social. Os municípios promovem a competição de cidadãos na decoração de cruzes, altares, pátios, cavalos e carroças (como um tipo de culto consumista), juntamente com várias competições profissionais, como pastores, motoristas de trator, pedreiros, etc. Por fim, refira-se o aumento significativo de jogos de futebol entre grupos sociais, como solteiros e casados, mordomos a entrar e de saída; em algumas aldeias enfrentam-se os vizinhos e aqueles que emigraram.

Por outro lado, "oferendas de flores" às padroeiras locais foram ritualizadas, tendo por modelo a festa do Pilar, em Saragoça, e a oferta à Virgem dos Desamparados, em Valência, competindo na entrega de milhares de ramos floridos. Quanto ao entretenimento de rua, multiplicam-se os clubes ou grupos de jovens, com camisolas e lenços da mesma cor e que participam animadamente nos vários eventos, com frequência acompanhados de fanfarra. Trata-se de um associativismo que emerge do âmbito ritual. Um fenómeno comum é que as inovações positivas para a comunidade são rapidamente integradas no ritual, e em pouco tempo tornam-se elementos tradicionais, como se "desde sempre".

\section{TENDÊNCIAS CONTEMPORÂNEAS}

A modernização dos rituais e intervenções que os transformam podem ser verticais (dos órgãos do poder) ou horizontais (por iniciativas espontâneas). Esse conflito

\footnotetext{
"Celebração junto do monumento escultural a Daoiz e Velarde, representando os militares que, juntamente com a heroína Manuela Malasaña, lideraram a revolução cidadã. No ano seguinte, em Zaragoza, foi recuperada a Cincomarzada, celebração de júbilo popular pela vitória sobre o ataque dos carlistas em 5 de março de 1838 , festa que tinha sido suprimida por Franco.

${ }^{12}$ Relatório do comandante do posto da Guarda Civil de Gor (Governo Civil de Granada, secção Fiestas)
} 
pode ser gerado entre grupos sociais com o mesmo estatuto (alto ou baixo); entre um grupo marginal e o resto da comunidade; e, mais frequentemente, entre as autoridades e os agentes da festa. Tal parece dever-se ao facto de o controlo dos ritos ter enorme importância para a organização social, ainda que pertença ao nível do simbólico.

Não se deve, todavia, ignorar as mudanças culturais que ocorreram nas últimas décadas a nível global. Em relação à mudança de atitudes e valores nos tempos modernos, caracterizada pela informatização e despovoamento rural, dentro do amplo contexto da globalização, não há dúvida de que afetam os modos de celebração das festas. Segundo Honorio M. Velasco (2000, pp. 116-119), surgem novos conflitos devidos a "ações eclesiásticas zelosas da ordem e pureza de atitudes em espaços religiosos", rejeição social de certos atos ligados à política e "presença maciça de turistas e visitantes"'3, que se acrescentam aos já habituais conflitos de tipo geracional e perda do autocontrolo de alguns por "euforia imparável". O autor aponta ainda o processo de "conversão em espetáculo de rituais festivos", juntamente com as "transgressões lúdicas em procissões e peregrinações", que derivam da secularização da sociedade. O que, embora pareça opor-se ao florescimento de certos "rituais da religiosidade popular", resulta dos "processos de identidade coletiva", que, num quadro de progressismo, revalorizam a cultura popular. De qualquer forma, a massificação de muitas festas tem por efeito serem menos desfrutadas.

Centrando-nos no período desde a III Restauração monárquica (1975), podem ser identificadas várias tendências fortes na evolução dos rituais ibéricos. Por um lado, a secularização evidente, que se manifesta tanto no calendário - com a supressão de muitos dias feriados do passado, ou sua transferência para o domingo mais próximo - e na eclosão de romarias profanas em detrimento das religiosas. Exemplos significativos dessas novas festas que estão classificadas como de Interesse Turístico são: as que correspondem a ofícios, como os Arrieros (Balsareny, Barcelona), os Pastores nas Astúrias (Cangas de Onís) e os Vaqueiros (Luarca); outras relacionadas com animais, como as da Matança (Burgo de Osma, Sória), do Cordeiro (Lena, Astúrias) e a Rapa das Bestas ou rodeios galegos de cavalos selvagens' ${ }^{14}$; por fim, em homenagem a elementos naturais, como a já antiga Rosa del Azafrán (Consuegra, desde 1963) e, em Toledo, da Oliveira (Mora), juntamente com a Exaltación del río Guadalquivir (Sanlucar de Barrameda, Cádis). Proliferam também os mercados onde artesãos mascarados oferecem os seus produtos, num regresso ao antigo comércio ambulante ${ }^{15}$. Destaca-se também o trabalho

\footnotetext{
${ }^{13}$ Um exemplo de massificação na galega Festa do Viño do Condado, que na sua XLVI edição, em 2005 contou com 20000 participantes, é o facto de o vinho já não ser distribuído gratuitamente, de modo a evitar incidentes.

${ }^{14}$ Em Sabucedo (A Estrada, Pontevedra), em vez de capturá-los com laço, os animais são derrubados com base na força e na destreza. Para os habitantes, a origem deve-se a uma praga que atacou a região no séc. XVI, quando duas irmãs prometeram oferecer a São Lourenço, padroeiro da paróquia, dois cavalos se ele os defendesse da praga. Tendo sido poupadas, entregaram-nos ao pároco, que os libertou no monte. Atualmente, a população local de cavalos ultrapassa os 2000 , dos quais 250 pertencem à igreja, que tem o direito exclusivo de possuir garanhões. Tradicionalmente, os cavalos desciam à aldeia uma vez por ano para lhes ser cortada a crina, remover os potros machos e marcar os outros. Para este efeito, foi construído um curral pedra ao lado da igreja no séc. XVIII.
}

${ }^{15}$ Exemplo de uma combinação de atividades é encontrado no muito recente mercado medieval em Cártama (Málaga), onde são oferecidos passeios de burro e tiro com arco. 
de associações culturais privadas, que organizam festivais que têm desempenhado um importante papel desde os anos 1980 no resgate de expressões folclóricas prestes a ser esquecidas, sendo o esquecimento equivalente à morte social. Nesse sentido, rituais de natureza muito diversa foram revitalizados.

Por outro lado, e na direção oposta, encontramos o fortalecimento das instituições cívico-religiosas como as confrarias e as irmandades. O ressurgimento das confrarias é visível no regresso às ruas dos rosarios de la Aurora; a celebração de romerías rocieras na Catalunha e em Madrid; e no aumento de penitentes e procissões ${ }^{16}$ na Semana Santa, época de auge para as pasiones vivientes ou a encenação da Via Sacra. Como exemplo ilustrativo, refira-se a Comunidade de Madrid, onde essa atividade de teatro popular começou em 1963, em Chinchón, sendo que em 2005 se celebram em seis localidades, destacando os mais de 300 atores e sete palcos de Aranjuez. Por sua vez, em Madrid, tornou-se tradicional celebrar o domingo de Páscoa com uma tamborrada sonora, que percorre a rua e a Plaza Mayor com mais de cem instrumentos de percussão (Una tamborrada en la plaza Mayor despide la Semana Santa, 2004).

Esta aparente contradição entre os dois processos simultâneos (Moreno, 1989, p. 19) é um fenómeno onde se detetam características como uma atitude mais ativa por parte dos fiéis que, perdendo o apoio institucional, tentam manter a sua capacidade de pressão com um novo espírito militante e de apoio mútuo; a adoção de atitudes lúdicas por parte de grupos sociais anteriormente distantes da diversão nas ruas; um reflexo da atual crise de ideologias e grupos políticos; e um reforço dos mecanismos de identificação de grupo.

Outro tipo de contradição reside na coexistência no mesmo âmbito territorial de formas festivas antigas e novas ${ }^{17}$. Exemplar é o caso da Comunidade de Madrid, onde, por um lado, persistem muitos rituais festivos "que nem suspeitávamos que perdurassem às portas da megalópole [mostrando que] as origens, metade de La Mancha e metade dos serranos, não foram esquecidas" (González, 1993, p. 11), enquanto, ao mesmo tempo, abundam os novos festejos profanos, como o festival do melão, da ida à água, da fundação da cidade, dos bairros, etc.

A segunda grande tendência é a do intervencionismo institucional, com as autoridades democráticas aplicando as suas ideias sobre cultura, o que se reflete em subsídios de órgãos públicos para potenciar certo tipo de tradições, como o retorno dos fossilizados coros e danças da Seção Feminina da Falange, ou, noutros casos, para favorecer a criatividade de grupos teatrais independentes.

Refira-se uma outra tendência relevante no quadro europeu. A partir de 1993, os projetos financiados pela União Europeia favoreceram a recuperação de rotas de gado, e rebanhos com milhares de ovelhas merino sulcavam os velhos desfiladeiros reais (entre os quais a rua Alcalá, em Madrid), sobre os quais reivindicavam direitos. Realizam-se também as festas de transumância no início do verão, nas localidades da Cañada Leonesa

\footnotetext{
${ }^{16}$ São em número elevado as crianças e os adolescentes que atravessam as ruas cobertos pelos capuzes.

${ }^{17}$ No País Basco, em plena modernização, a dança "dos homens", "de corda" ou mais conhecida como aurresku, o nome do primeiro dançarino da corda, o mais hábil e responsável pela condução da dança, ainda é generalizada.
} 
oriental e da Via da Prata, onde os vizinhos saem ao encontro dos rebanhos e acolhem os pastores. A integração na União Europeia trouxe às localidades novos residentes, especialmente em áreas turísticas, o que originou festas como a Oktoberfest ou da Cerveja (pelos alemães; em Andratx, Calella, Calpe, Torremolinos, Vigo ...) e Dragonfest, que celebra a chegada da primavera em março junto ao rio em Orjiva. Criada em 1996, por uma colónia de residentes ingleses, esta última foi divulgada no estrangeiro, atraindo centenas de neohippies. Sem organizadores, os participantes desfrutam de concertos e drogas variados e, embora tenha sido proibido pelo município, em 2002 reuniu cerca de 3000 pessoas ${ }^{18}$. Na sua senda, surgiram outras festividades de primavera espontâneas em Granada e Sevilha' ${ }^{19}$. Menos problemáticas são as festas específicas das novas comunidades de imigrantes, como o Ano Novo Chinês, que leva os seus desfiles coloridos com dragões de papel até às ruas de Madrid, e as reuniões de senegaleses e equatorianos em vários locais, numa miscigenação cultural que traz novos modos de divertimento.

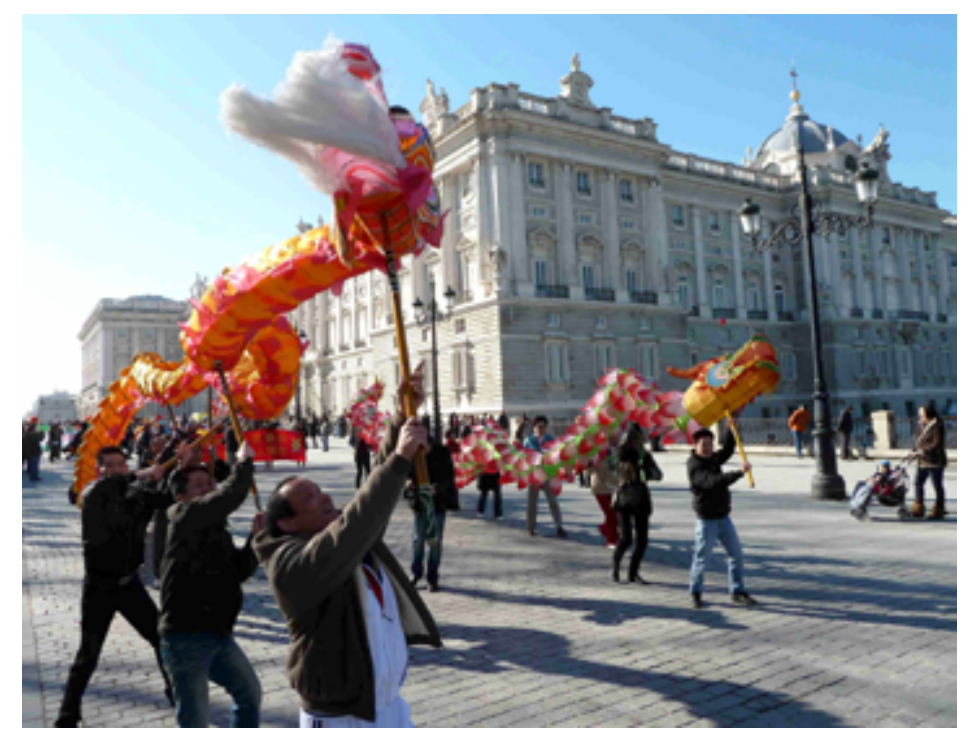

Figura 3: Ano Novo Chinês em frente ao palácio Real em Madrid (2012) Créditos: Demetrio Brisset

Uma novidade de relevo é a incorporação maciça e irreversível das mulheres nas atividades festivas, tanto no papel de membros organizadores, quanto na sua participação como personagens ativos. Por vezes, conseguiram mesmo manter algumas danças rituais que já não se faziam, substituindo os homens ${ }^{20}$. Este uso de um espaço social de propriedade masculina, exigiu em certos casos um grande esforço, como testemunham

\footnotetext{
${ }^{18} \mathrm{~A}$ morte de dois participantes por overdose e a campanha mediática montada, além dos rígidos controlos de acesso, resultaram na diminuição de participantes para 1.500 em 2003. Foi depois criada, em 2005, uma infraestrutura logística adequada à assistência massiva.

${ }^{19} \mathrm{Em}$ Granada, começou no Paseo de los Tristes e, perante os protestos do bairro por causa do ruído, em 2005 foi transferida pelas autoridades municipais para um recinto nos arredores. Todavia, os habitantes conseguiram que fosse proibida, o que resultou num enorme botellón. Quanto a Sevilha, a divulgação online levou cerca de 70 ooo pessoas a Cartuja.

${ }^{20}$ Destaca-se o caso de Finisterra (Corunha), onde as mulheres são responsáveis pela dança de paus, substituindo os homens, que costumavam fazê-la com espadas.
} 
os conflitos pela inclusão feminina nas soldadescas bascas e nos costaleros andaluzes. Juntamente com a sua participação nas touradas, um dos exemplos mais impressionantes da igualdade conquistada é que também as mulheres pisam descalças o tapete de brasas na noite de São João ${ }^{21}$ e saem à noite para cortejar os rapazes.

Fora do âmbito religioso, existem as associações dinamizadoras que exportam o seu modelo organizacional de uma localidade para outra, concorrendo para a criação de festas semelhantes. Exemplos disso são as entidades que promovem a divulgação de festas de tipo histórico. Por fim, é percetível a exaltação do tema militar, de que são exemplo o vestuário, os desfiles e a música marcial, tanto nas representações de Mouros e Cristãos como noutras festas.

\section{AS COMEMORAÇÕES CÍVICO-HISTÓRICAS}

Entre as representações rituais hispânicas de luta entre duas fações, e de base histórica, foram privilegiadas, durante o regime de Franco, as de Mouros e Cristãos, que recordam a conquista medieval da própria localidade por tropas com a bandeira da Cruz. Nelas revela-se um discurso patriótico-religioso intolerante, consonante com a mentalidade política dominante.

O exemplo mais antigo é ainda representado hoje num recanto das serranias isoladas de Cabrera Alta, em Leon, na área onde os romanos exploravam as minas de ouro de Las Médulas com mão-de-obra escrava. Trata-se da dança do rei Nabucodonosor, em referência ao rei da Babilónia que conquistou Jerusalém em 587 s.C., representando um chefe mouro, enquanto o profeta Daniel representa o seu antagonista, o embaixador cristão ${ }^{22}$. Um elevado nível de anacronismo está geralmente presente em muitas representações de Mouros e Cristãos, revelando um certo caráter de conto de fadas sacramental.

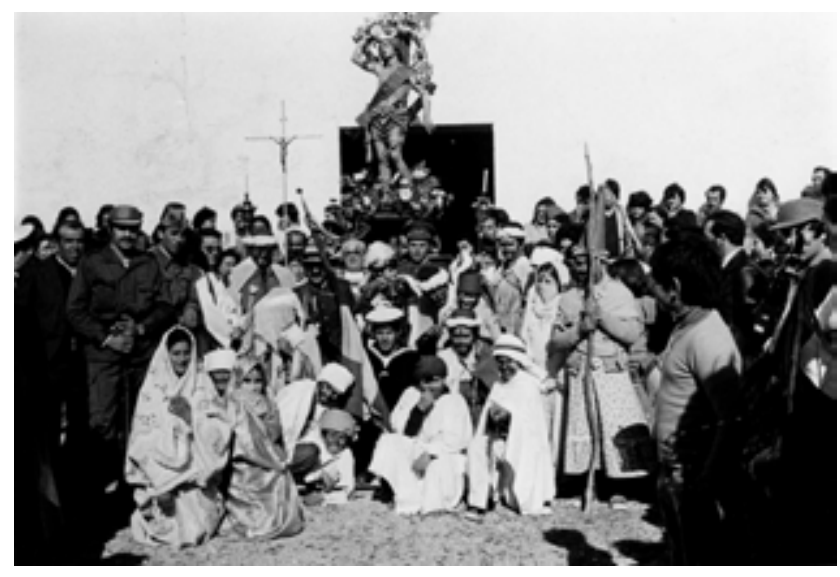

Figura 4: Mouros e Cristãos de Orce (1981) Créditos: Demetrio Brisset

\footnotetext{
${ }^{21}$ No San Pedro Manrique, Sória. Em relação a correr en los encierros, em Navarra, fizeram-se desde 1955; o alarde misto começou em Irún em 1997; e duas costaleras sairam em Córdoba em 2001.

${ }^{22}$ É realizada na localidade de Corporales em honra da Virgem de Agosto, embora anteriormente fosse comemorada por ocasião do Corpus Christi.
} 


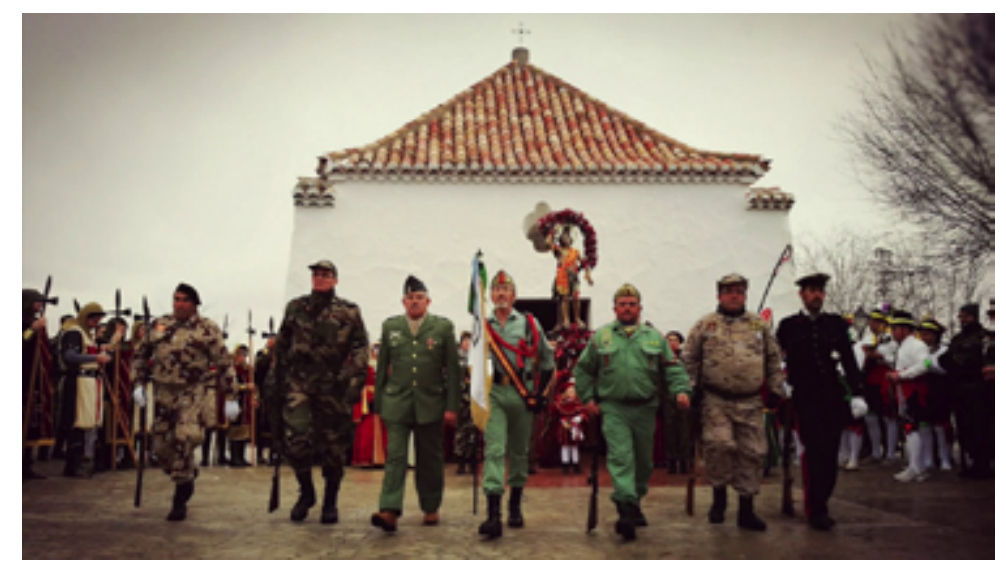

Figura 5: Mouros e Cristãos de Orce (2017)

Fonte: https://www.granadaaltiplano.org/

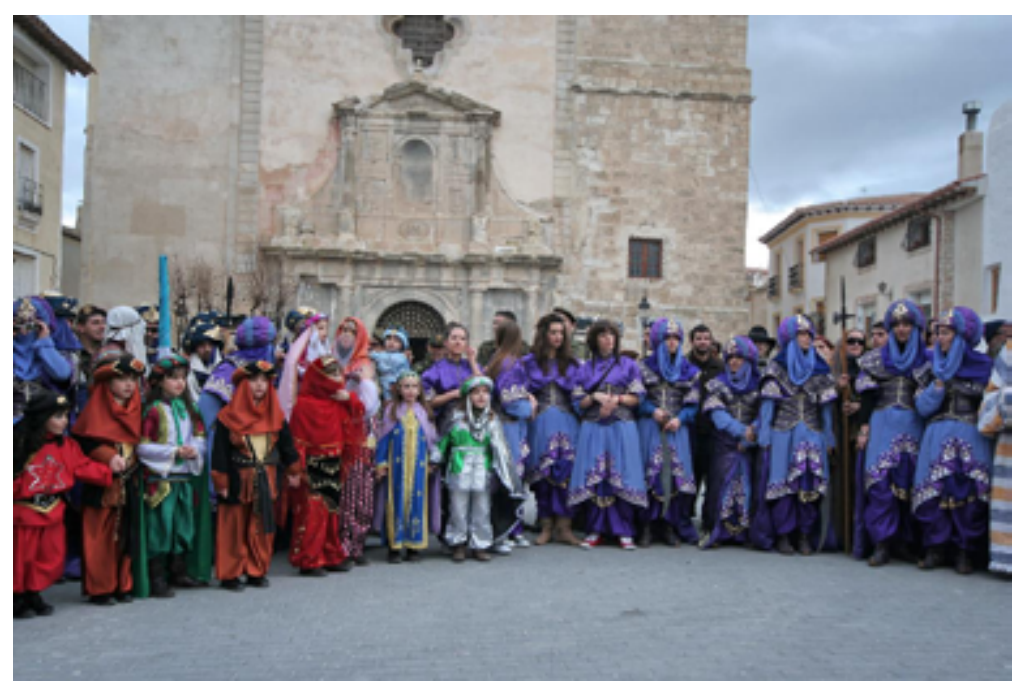

Figura 6: Mouros e Cristãos de Orce (2018)

Fonte: https://www.granadaaltiplano.org/

O início da renovação destas rígidas representações populares ocorreu em 1976 em Campo de Mirra (Alicante), quando a partir dos documentos existente foi incorporada a representação do Tratado de Almizrra (1244), o acordo assinado entre aragoneses e castelhanos para delimitar o Reino de Valência. A partir de 1977, os eventos da festa foram rigorosamente ajustados aos acontecimentos (Francés \& Francés, 1986, p. 286). Naquele ano, o mesmo autor (Salvador Doménech) refaz os textos das Embaixadas da vizinha Crevillente, para refletir os factos históricos conhecidos.

Quanto à rotura ideológica, ocorreu em Múrcia, em 1983, quando um alcoyano e vários professores universitários criaram os debates e iniciativas para a Comemoração da fundação da cidade, lembrando a sua edificação por Abderramán II, a entrada de Afonso $X$, a sua negociação com o rei Aben-Hud e a rendição deste, entregando as chaves da cidade. São, assim, recuperadas as antigas festas de Mouros e Cristãos de Múrcia, mantendo o esquema das duas fações, mas eliminando a religiosidade e o belicismo (Francés \& Francés, 1986, p. 286; Capel, 2001, pp. 13-21). 
Para a maioria dos membros da UNDEF (União Nacional das Entidades Festivas), criada em 1976 e responsável por garantir a ortodoxia das festas de Mouros e Cristãos, com este modelo murciano perderam-se características essenciais destas festas. Mas, apesar da sua rejeição oficial, a nova proposta atraiu adeptos entre jovens festeiros que preferiam a diversão à doutrinação, e surgiram variantes com outros grupos que desenvolviam atividades típicas de tais festas, como desfiles, combates e montagem de acampamentos festivos para cada um dos subgrupos das formações.

Em 1979, uma nova etapa foi inaugurada na Galiza nas "lutas entre duas fações para conquistar um castelo", com o Assalto ao castelo dos Andrade, em Moeche, a cargo dos vizinhos, representando o levantamento dos irmandiños em 1431, que exigiram liberdade contra seu despótico senhor feudal23.

Em Aranjuez, surgiu em 1980 (Sánchez, 1998, p. 442) uma grotesca Descida de Piratas pelo Tejo em barcos surrealistas, expandindo-se em 1983 para a festa cívico-teatral conhecido como Fiestas del Motín, recordando a revolta popular contra o primeiro-ministro Godoy entre 17 e 19 de março de 1808, que causou a abdicação do rei Carlos IV. Os factos históricos são representados pelos locais, com trajes de época, nos cenários em que ocorreram: assalto ao Palácio Godoy (com Godoy simbolizado por uma boneca de palha) e ao pátio do Palácio Real24.

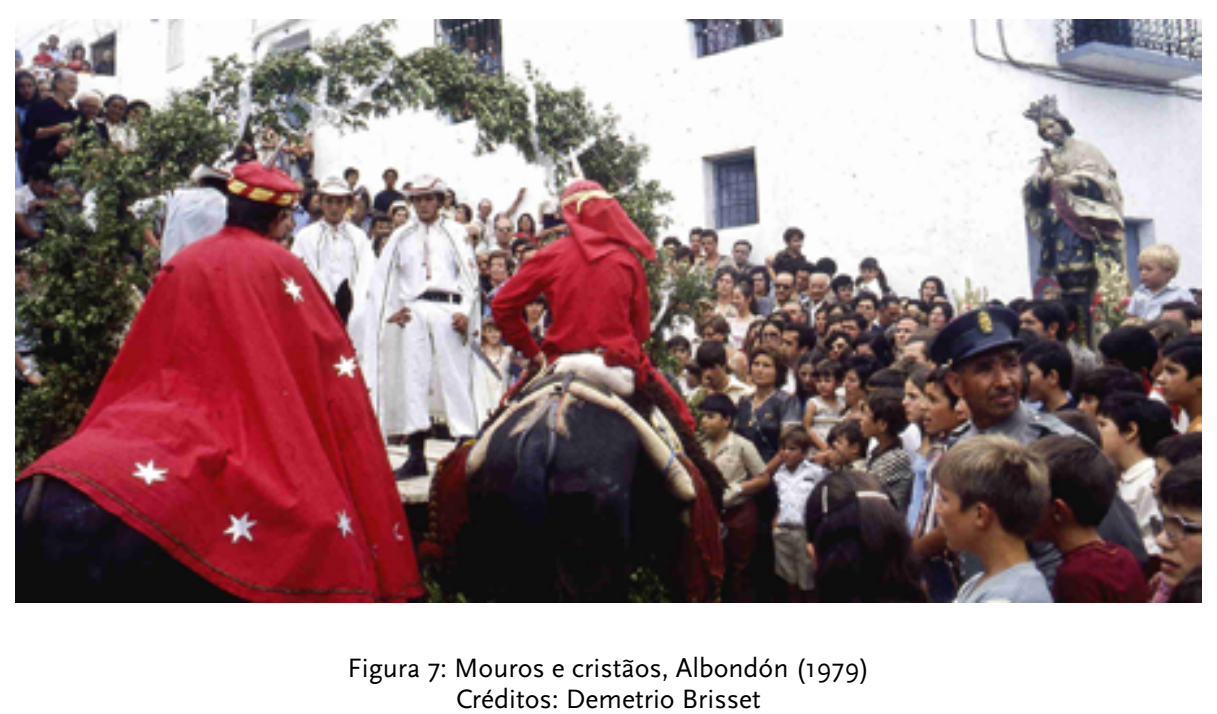

\footnotetext{
${ }^{23} \mathrm{~A}$ revolta dos irmandiños, ou irmandade popular das comarcas de Pontedeume e Betanzos, destruiu o castelo onde residia Nuño Freire de Andrade, O Mao (El Malo), que fugiu para Santiago buscando proteção contra o arcebispo. Depois de reorganizar as suas hostes, ele derrotou o povo revoltado na batalha do Eume. Os participantes da festiva Marcha Irmandiña, em meados de agosto, percorrem a pé o caminho entre o mosteiro de Narón e o castelo de Moeche (de propriedade da Casa de Alba, província da Corunha), o qual conquistam à noite. Em 2005, a comissão de festas apenas teve apoio financeiro das instituições.

${ }^{24} \mathrm{Na}$ mesma Comunidade de Madrid, outra festa de base histórica foi instituída em 1994: o Levantamiento contra los franceses, convocado pelos líderes de Móstoles e com o qual declararam guerra aos franceses. Os participantes lembram a eclosão da luta popular de 2 de maio, com cerca de 350 pessoas vestidas como alcaides, militares e camponeses. Em 2 de maio de 1985, o alcaide assinou uma declaração de paz com o embaixador francês, e a Comunidade de Madrid assumiu essa festa como sua. Com uma feição menos rebelde, é lembrada recentemente em Navalcarnero a boda de Filipe IV com Mariana da Áustria, no último fim de semana de agosto.
} 


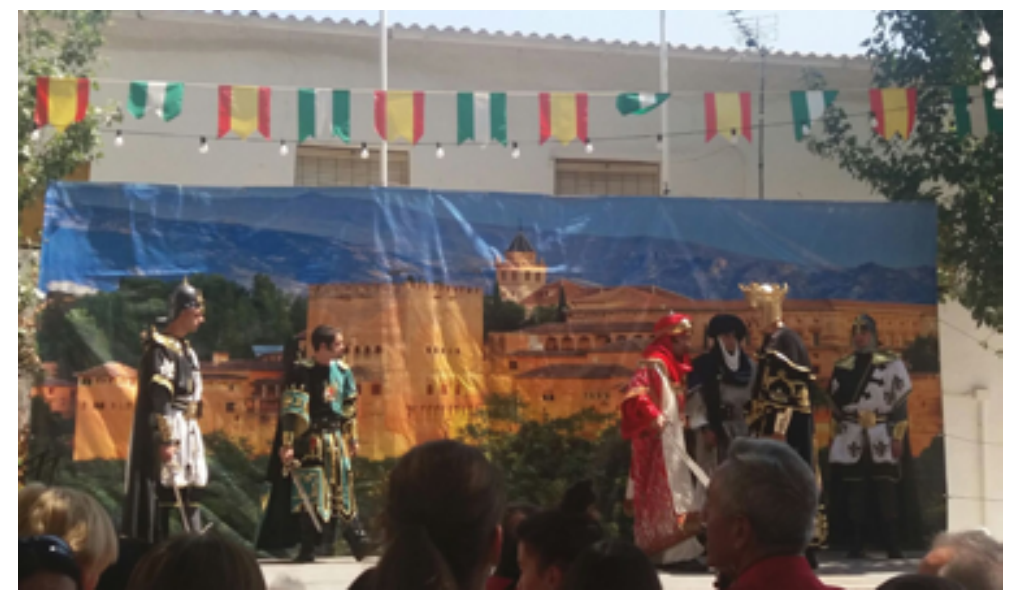

Figura 8: Mouros e cristãos, Albondón (1979) Créditos: Miguel Carvajal

Mais estruturada é a variante iniciada em Cartagena, em 1990, com as suas Festas de Cartagineses e Romanos, que revivem os acontecimentos dos anos 223-209 a.C, quando a cidade passou de Qart-Hadast a Carthago Nova. Devido ao sucesso da iniciativa, os 500 narradores iniciais aumentaram até aos 5000, expandindo os atos profanos, que em 2001 consistiam numa extensa sequência: acender o fogo sagrado, juramento de inimizade a Roma, fundação de Qart-Hadast, destruição de Sagunto, declaração de guerra do Senado romano, casamento de Aníbal e da princesa ibérica Himilce, oráculo de Tanit, circo romano, desembarque do exército cartaginense, desfile da partida de Aníbal para Roma, desembarque romano, grande batalha pela conquista de Qart-Hadast, desfile vitorioso de Cipião, homenagem aos romanos mortos em batalha, proclamação do direito romano. Esta lição viva de história acerca da Segunda Guerra Púnica, sobre as ruínas arqueológicas e com um acampamento, é organizada pela Federação de Tropas e Legiões, estruturando associações relacionadas com as filáes de Mouros e Cristãos, os grupos falleros ou os cuarteles da Semana da Páscoa de outras localidades ${ }^{25}$. Esta maneira de unir cultura, história, espetáculo e diversão popular foi rapidamente imitada.

$\mathrm{Na}$ Corunha, para valorizar a comemoração da batalha de Elviña (que ali ocorreu em 1809, quando as tropas inglesas chegaram em fuga do exército napoleónico do marechal Soult), foi fundada, em 1996, a Associação Histórico-Cultural The Royal Green Jackets, empenhada em organizar recriações históricas de acontecimentos ligados à Guerra da Independência. Em 2003, os Green Jackets colaboraram na realização da Primeira Recriação Histórica da Batalha de Medina de Rioseco (Valladolid), com desfiles, concertos de bandas militares, tenda-museu militar e representação bélica.

\footnotetext{
${ }^{25}$ Como precedente temático, só conheço uma dança no Corpus Christi de 1593, em Oviedo: o Triunfo de Escipión contra Aníbal Africano, que tinha um carro triunfal no qual algumas ninfas acompanhavam o general romano (Valdez, 1983, p. 55), embora acredite que o assunto histórico deverá ter sido representado nos teatros da Península Ibérica romana.
} 


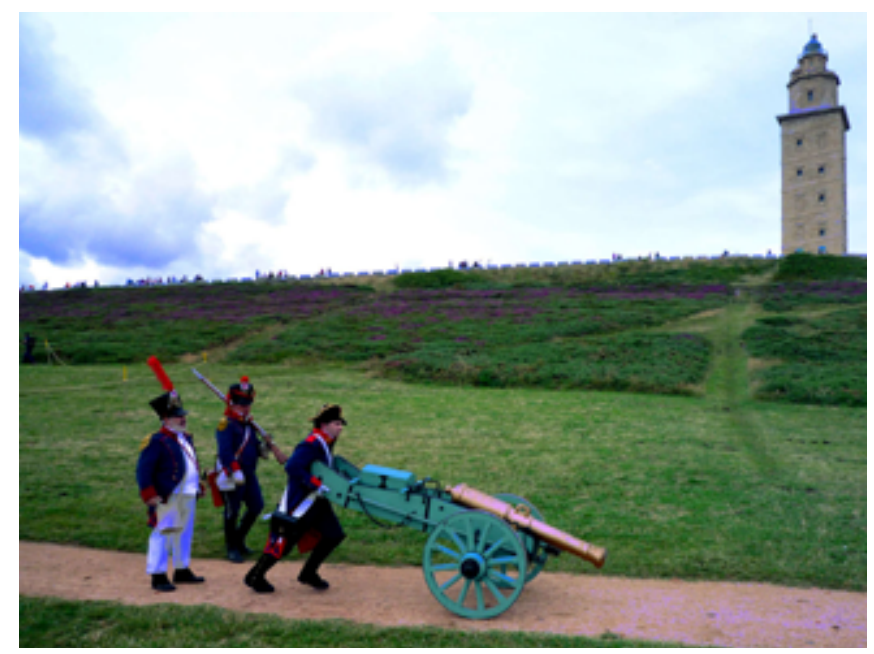

Figura 9: Recriação da Batalha de Elviña de 1809, A Coruña (2009) Créditos: Demetrio Brisset

O precedente dessas reconstituições de batalhas pode ser aquele que comemorou o que ocorreu em Bailén, em 19 de julho de 1808, quando as tropas do general Castaño derrotaram as napoleónicas e assim começou a sua expulsão do país. Um desfile com personagens vestidos ao estilo da Guerra da Independência complementa a procissão com a padroeira de Bailén, a Virgem da Zocueca (que detém o posto de Capitão General e a quem foi atribuído apoio decisivo na luta). Desde 1890 o Exército participa nesta festa, de clara exaltação militar.

Uma variante interessante é a de Macharaviaya, em Málaga, onde Bernaldo de Gálvez nasceu numa família de militares ilustrados. Nomeado governador da Luisiana, entre 1789 e 1791, ajudou os colonos americanos a alcançar a independência, controlando o Mississippi e derrotando as tropas britânicas em várias batalhas, especialmente a de Pensacola. Desde 2009, por volta de 4 de julho, os habitantes da localidade recriam essa batalha com grande rigor histórico.

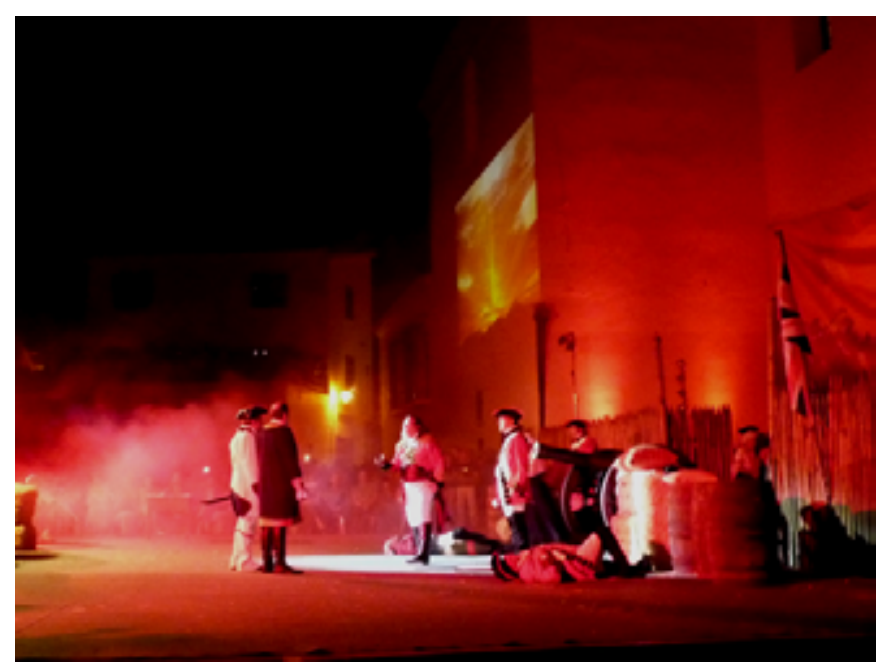

Figura 10: Batalha de Pensacola - rendição dos ingleses, Macharaviaya (2017) Créditos: Demetrio Brisset 
Por outro lado, no Palácio Real foram promovidas as paradas ou revistas ${ }^{26} \mathrm{com}$ tropas vestidas com uniformes de época, como os membros do Regimento Imemorial do Rei, que remontam a 1696 e são consideradas as mais antigas do mundo, e os alabardeiros empunhando as suas armas de aço afiadas.

\section{INTEGRAÇÃO NAS FESTAS EUROPEIAS}

Para uma sociedade em processo de modernização e laicismo, a nova orientação festiva oferece grandes possibilidades. Cartagena convocou em 2000 um encontro de festivais históricos, com a participação de 12, e daí resultou a fundação da Associação Espanhola de Festivais e Recriações Históricas, que seria integrada na federação europeia $^{27}$, criada em 1991 a partir de festas italianas e francesas e com base no desporto antigo de besta de tiro com arco. Esta associação, cujo objetivo é "reivindicar e promover a história dos diferentes pontos geográficos da Espanha, através das festas, (...) unindo esforços [e] melhorando a qualidade e enriquecendo-as (...) com base em experiências alheias", procura difundir o "orgulho especial (...) de ser protagonista ativo de um evento histórico e irrepetível" e pretende agrupar as festas "que são organizadas em celebração de um acontecimento anterior ao ano 1900, [podendo] inspirar-se num facto ou evento histórico, ou também em lendas, ficções literárias ou em épocas específicas da nossa história". É considerada histórica uma festa que "provou a sua celebração periódica e tem rigor e fidelidade aos factos que estão na sua origem (...) respeitando a estética da época em questão" ${ }^{28}$.

A esta associação pertencem as entidades que organizam festas como: Sodales ibero-romanos (séc. I), em Fortuna, Múrcia; Fiesta del Charco ou ritos aborígenes, San Nicolás de Tolentino, Las Palmas; La Morisma (séc. VIII), Aínsa, Huesca; Cerco ao castelo (1097), Consuegra, Toledo; as Bodas de Isabel de Segura (séc. XIII), Teruel; Festas medievais, com a chegada de Blanca da Sićlia à corte do rei de Navarra, Olite ${ }^{29}$; a lenda de San Jordi (1414), Montblanc, Tarragona; Fiesta del Escudo ou ataque mouro do Sábado Santo (1477), Cieza, Múrcia; Festa do Renaixement ou das milícias de defesa (séc. XVI), Tortosa, Tarragona; Fiesta de los Conversos (séc. XVI), Hervás, Cáceres; El alcalde de Zalamea (séc. XVII), Zalamea, Badajoz; os Tres Blasones de España, comédia de santos (séc. XVII), Calahorra, La Rioja; Incursiones Berberiscas no Mar Menor, Los Alcázares, Múrcia; e, finalmente, a curiosa La España de Rojas, La Puebla de Montalbán, Toledo, que recria um auto-de-fé inquisitorial no séc. XV, com os seus hereges queimados.

Voltando às recreações das batalhas da Guerra da Independência, pelo $200^{\circ}$ aniversário da Batalha de Elviña (Corunha, 2009), cerca de 700 pessoas participaram vestidas

\footnotetext{
${ }^{26}$ Como o desfile militar que é televisionado a cada 12 de outubro.

${ }^{27}$ Federação Europeia de Festas e Manifestações Históricas. Entre os atuais representantes espanhóis, um é ao mesmo tempo secretário do UNDEF, o que mostra o vínculo entre estas organizações.

${ }^{28}$ Estatutos de la Associação Espanhola de Festivais e Recriações Históricas, artigos $24^{\circ}, 25^{\circ}$ e $27^{\circ}$. Retirado de www.imaengine.com.

${ }^{29}$ Essa representação histórica começou em 1994, com uma subvenção do programa europeu Leader II. A chegada da rainha foi incorporada em 2001.
} 
com imitações de uniformes da época, entre as quais membros de grupos napoleónicos de França, Grã-Bretanha, Itália e Rússia, enfatizando a morte do general Moore e o reembarque da expedição britânica.

Neste tipo de recreações, colabora geralmente a Associação Napoleónica Espanhola $^{30}$ (a que pertencem grupos de Madrid, San Sebastián, Valência e Saragoça), e quando uma batalha tem mais de 400 participantes é considerada de classe A. Em 2005, as mais numerosas foram as de Bailén (Jaén), Castalla (Alicante), La Albuera (Badajoz) e Brión (Corunha) - e outras nove ocorreram naquele ano. Como se pode verificar, o sentimento anti-napoleónico tornou-se moda no séc. XXI, tal como o anti-império romano, cujos triunfos cruéis sobre a Galiza, Numância e Cantábria são ritualmente vingados ${ }^{31}$.

\section{NoVAS FESTIVIDADES HISTÓRICAS E PAGÃS NA GALIZA}

A cada ano são mais numerosas as festas deste novo tipo, que podem ser consideradas históricas e que se estendem por todo o Estado espanhol. Como elementos comuns encontramos a elevada participação popular em espetáculos de teatro de rua; ausência de vínculos com a liturgia católica; uso de trajes antigos; promoção do orgulho relativamente a acontecimentos do passado coletivo.

Lembremos o que Hobsbawm diz acerca do indispensável contributo social dos historiadores:

em primeiro lugar, a memória. Hoje, as pessoas esquecem facilmente. Em segundo lugar, corrigir, porque eles sabem o que aconteceu no passado. Vivemos em países com muitos anos e cada um pretende reconstruir um passado que não tem nada a ver com sua verdadeira história (...) A crítica à retórica dos mitos históricos é uma tarefa dos historiadores de hoje. (Intxausti, 2003, s.p.)

Porém, sendo demasiado extenso investigar a evolução das festividades pós-modernas no país como um todo, limitar-nos-emos a destacar algumas da Galiza32:

A Festa da Istoria celebra, desde 1989, em Ribadavia, o seu esplendor medieval, quando era a capital do reino da Galiza. Os produtos consumidos são pagos em maravedis, que era a moeda de curso legal. $O$ desfile conta com cerca de 3000 pessoas vestidas com trajes de época. Uma boda Xudea evoca o passado judeu da cidade; desde 2002, culmina com uma procissão das almas ${ }^{33}$.

\footnotetext{
${ }^{30}$ É responsável por preparar o calendário das batalhas, assessorar as autoridades municipais na organização dos eventos e coordenar os diferentes grupos de recreação, a nível nacional e internacional (La Voz de Galicia, 2005). Na Europa, realizam-se recriações de guerra desde antes de 1980 e também estão em pleno apogeu, de que é exemplo a recriação do cerco e da conquista do Castelo de Vyborg na Rússia, desde 1996, com a participação de mais de 50 associações de aficionados de localidades russas em 2005.

${ }^{31}$ Para lá das lutas contra os celtas, comemoram-se também as Guerras Numantinas (séc. II a.C.) em Garray (Soria) e as Guerras Cantábricas (séc. I a.C.) em Los Corrales de Buelna (Cantábria).

${ }^{32}$ Os dados recolhidos pessoalmente foram complementados pelos dados fornecidos por Omayra Lista e Tania Saldaña (2004, pp. 8-109). Várias destas festividades estão integrados na Federação Europeia de Celebrações Históricas.

33 Têm lugar também torneios, tiro com arco e falcoaria, na província de Ourense, no último fim de semana de agosto.
} 
No Asalto al castillo de Vimianzo, desde 1995, um grupo de rebeldes com tochas de palha acesas assalta o castelo dos condes de Altamira, sendo motivado pelos gritos das mulheres: "Abaixo as fortalezas!". O assalto popular de 1467 é recordado com uma encenação marcante, que inclui aríetes, bruxas, padres e lutas com um resultado incerto ${ }^{34}$.

Desde 1997, na Reconquista de Vigo centenas de moradores de Vigo encenam a libertação da cidade dos ocupantes franceses em 1809, como resultado de uma conspiração das autoridades de Vigo, com o apoio de alguns portugueses e de navios ingleses. A encenação inclui a façanha de Cachamuiña, destruindo uma das portas com machados, apesar de ter sido ferida por 4 tiros, bem como a tropa francesa sendo levada como prisioneira para um navio inglês ${ }^{35}$.

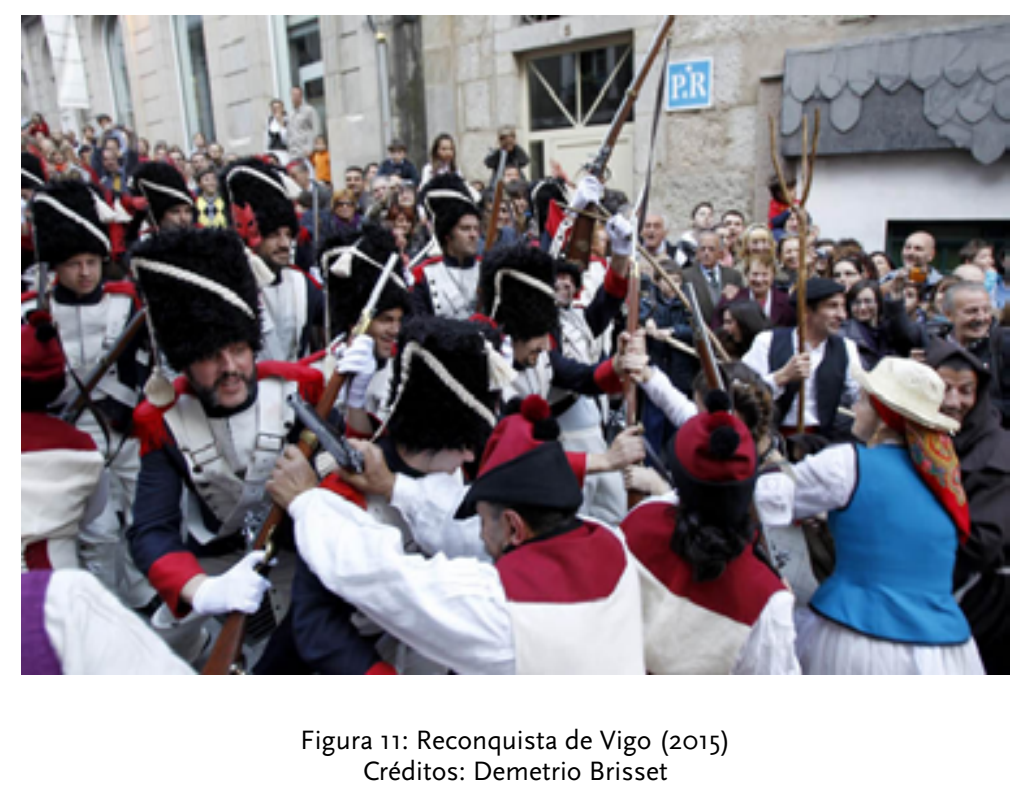

Em Xinzo de Limia, com o apoio de festeiros de Cartagena, começou em 2001 a Festa do Esquecemento, em memória de um facto ocorrido por volta do ano 137, aquando da conquista da Galiza pelos romanos. Quando chegaram ao rio Lethes (hoje o Lima), os romanos amedrontaram-se com a lenda galega de que perderiam a memória aqueles que o atravessassem. Permaneceram paralisados na margem até o general Décimo Junio Bruto erguer um estandarte e atravessar o leito do rio sozinho, chamando os seus homens pelo nome e, ao demonstrar que não se havia esquecido, é então seguido pelas tropas. Sucedem-se atos como a "oferenda Ara Solaris" ao nascer do sol, com desafios entre duas fações, seguidos pela encenação da passagem da água e pela batalha entre castrejos e romanos, licitação de escravos, queimada da fraternidade e apagamento do fogo sagrado Além de um circo romano e um templo de Baco, existem eventos nos acampamentos, onde é necessário disfarçar-se: os jovens preferem ir de bárbaros,

\footnotetext{
${ }^{34}$ Culmina com um concerto de folclore celta, província da Corunha, início do mês de julho.

${ }^{35}$ Fim de semana próximo do dia 28 de março, com direção artística do grupo Tanxarina.
} 
ficando em cabanas improvisadas (como as de Os fillos de Chingasvinte), enquanto os mais velhos vão como romanos e desfrutam de luxuosas e bem abastecidas tendas ${ }^{36}$.

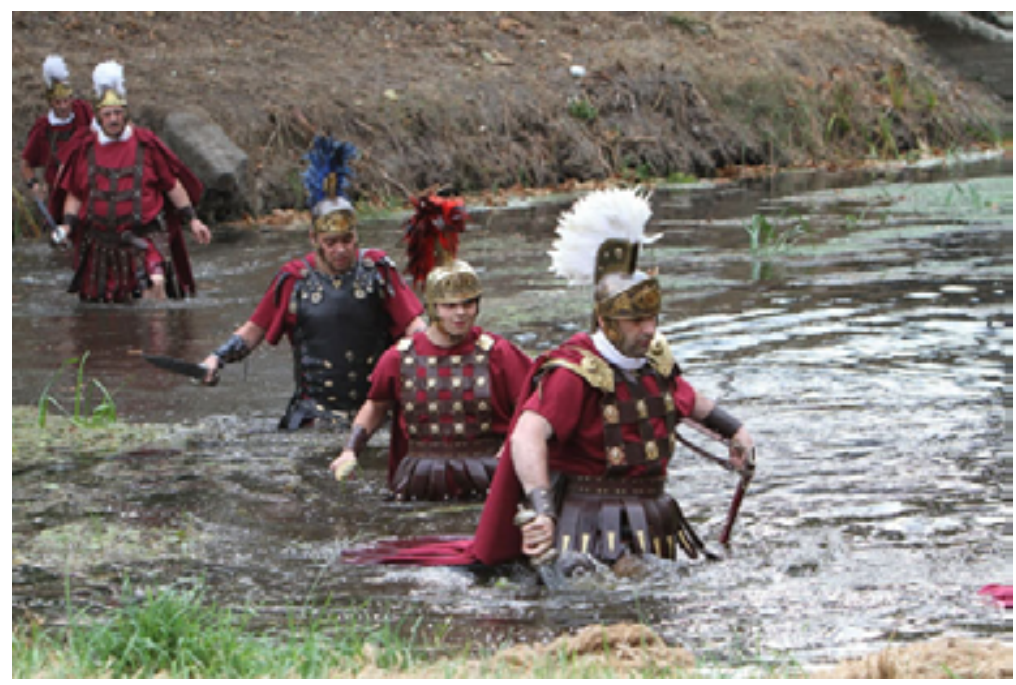

Figura 12: Festa do Esquecemento, Xinzo de Limia, Ourense (2011) Créditos: Iñaki Osorio

Arde Lucus decorre no solstício de verão em Lugo, comemorando a fundação da cidade em 14 a.C. por ordem do imperador Augusto, e inclui oferenda ao deus celta Lugh (a luz), combate de gladiadores, venda de escravos, constituição do Senado, irmandade de legiões de outros festivais romanos (Cartagena, Xinzo, ...).

A Feira Franca Medieval, em Betanzos, celebra o privilégio real de 1340 que a criou; o fogo de 1569 é recriado, assim como a prisão e expulsão dos leprosos da cidade ${ }^{37}$. Similarmente, refira-se a Festa Medieval, em Maceda, com um julgamento de bruxas ${ }^{38}$.

Ao mesmo tempo que se deteta a tendência de procurar rigor histórico nas encenações festivas dos triunfos locais, remontando ao período do domínio romano, têm surgido desde o início do séc. XXI novos festejos ligados a crenças pagãs, ampliando o âmbito temporal das celebrações até tempos do passado coletivo tão distantes (pré-históricos até) que dificilmente podem ser documentados. Em relação a estas novas festas pagãs, mencionaremos apenas algumas que remetem para a cultura castreja ou aos castros celtas, que floresceram a partir do séc. VI a.C39:

Festa da Lua Cheia, com a queimada de 3500 litros de aguardente a cargo do bruxo e de meigas, que remonta a 1979.

\footnotetext{
${ }^{36}$ É coroado Décimo como Gallaecus, cônsul de Roma. Província de Ourense, penúltimo fim de semana de agosto.

${ }^{37}$ Província da Corunha, mês de julho.

${ }^{38}$ Província de Ourense, meados de agosto.

${ }^{39} \mathrm{~A}$ antiga queimada ou halloween enxebre um Cervo (Lugo), a meados de agosto; o encuentro em Mos, perto de Vigo (Pontevedra), 21 domingo de agosto; a aureana em Neda (A Coruña), mês de junho; Lungnasad em Bretoña (A Pastoriza, Lugo), primeira sexta feira de agosto; a ninfa Tanitaco em Xunquera de Ambia (Ourense), finais de julho; o oenach em Sedes (Narón, A Coruña), último fim de semana de agosto. Foi tal o êxito de Lungnasad, criado em 1995, que para não continuar a apoiar o envolvimento de forasteiros, em 2005 foi organizada quase em segredo, sendo 21 os casais que trocavam folhas de louro junto à pedra dos namorados.
} 
Encontro Tribal junto a uma mamoa (monumento de pedra pré-histórico), onde centenas de pessoas cobertas de peles se envolvem em jogos trogloditas e oficinas de fabricação de ferramentas de pedra e metal.

Feira Celta Aureana, no monte onde se encontra a mítica fonte Aureana, reputada como tendo propriedades sagradas, com narrativa da lenda celta.

$\mathrm{Na}$ Festa Celta de Lugnasad ou do verão, celebram-se junto ao castro bodas seguindo o rito celta, válidos por um ano e oficiados pelo druida mayor da Galiza, que depois abençoa uma grande queimada.

Festa castrexa, com oferenda à ninfa Tanitaco, deusa das águas, a qual é levada da cidade até ao rio, seguindo a rota romana. Inclui ainda boda celta e queimada.

Oenach (encontro) Celta, com a reconquista do assentamento pré-romano.

Estou convicto de que podemos vaticinar ampla descendência para estas festas em contraponto aos modelos impostos durante séculos. São, de facto, expoentes de festas libertárias, que conseguiram sobreviver apesar das perseguições que lhes foram movidas.

Tradução: Rita Ribeiro

\section{REFERÊNCIAS}

Cabada, M. (1992). A rapa das bestas de Sabucedo. Historia e antropoloxía dunha tradición. Vigo: Ed. Ir Indo.

Capel, J. J. (2001). Origen histórico y argumentos de las Fiestas de Moros y Cristianos de Murcia. In R. Montes (Ed.), Moros y Cristianos (pp. 13-21). Murcia.

Casarrubios, C. G. (1993). Fiestas Populares del ciclo de primavera en la Comunidad de Madrid. Madrid: CEAC.

Díaz, M. del M., Blanco, J. \& Saldaña T. (2004). Fiestas gastronómicas (Galicia). Corunha: La Voz de Galicia.

Francés, R. \& Francés, J. M. (1986). Aportación de Campo de Mirra a los valores esenciales de la Fiesta de Moros y Cristianos. Actas do Il Congreso Nacional de la Fiesta de Moros y Cristianos (pp. 285-286). Ontinyent: UNDEF.

Intxausti, A. (2003, 12 de abril). El comunismo continúa vigente como motivación y como utopía. Entrevista a Eric Hobsbawn. El País. Retirado de https://elpais.com/diario/2003/04/12/cultura/1050098401_850215. html

La Voz de Galicia (23 de agosto de 2005).

Lista, O. \& Saldaña, T. (2004). Fiestas Históricas (Galicia). Corunha: La Voz de Galicia,

Ministerio de Información y Turismo (1973). Calendario Turístico 1974. Madrid.

Moreno, I. (1989). El estudio de los grupos para el ritual: una aproximación. In M. Luna (Ed.), Grupos para el ritual festivo (pp. 15-21). Murcia: Editora Regional.

Sánchez, M. A. (1998). Fiestas Populares. Madrid: Maeva.

Una tamborrada en la plaza Mayor despide la Semana Santa (2004, 11 de abril). El País. Retirado de https:// elpais.com/diario/2004/04/11/madrid/1081682658_850215.html 
Valdez, C. C. G. (1983). El teatro en Oviedo 1498-1700. Oviedo: CSIC-Univ.

Velasco, H. M. (2000). Tiempos modernos para fiestas tradicionales. In F. J. García Castaño (Ed.), Fiesta, tradición y cambio (pp. 99-128). Granada: Proyecto Sur Ed.

\section{NotA BIOGRÁFICA}

Demetrio Brisset é Professor Catedrático Emérito da Faculdade de Comunicação da Universidade de Málaga (2017), onde foi Professor de Antropologia Audiovisual desde 1993. Doutor em Jornalismo pela Universidade Complutense de Madrid (1988). Especializou-se em análise audiovisual e história e simbologia das festas. Realizou trabalho de campo por toda a Espanha e entre comunidades indígenas no México, Guatemala, Equador, Peru e Bolívia. Entre seus livros destacam-se Las puertas del poder: 'El Proceso' de Kafka y Welles como gestos de rebeldía (2013); Análisis fílmico y audiovisual (2011); La rebeldía festiva. Historias de las fiestas ibéricas (2009); Fotos y Cultura (2002); Los mensajes audiovisuales (1996); Fiestas de Moros y Cristianos en Granada (1988).

ORCID: https://orcid.org/oooo-0002-2546-769X

Email: brisset@uma.es

Morada: Faculdade de Ciências da Comunicação, Campus de Teatinos, Universidade de Málaga, Espanha

\section{Submetido: 12.05.2019}

Aceite: 07.09 .2019 